Економічні науки: збірник наукових праџь Луцького національного технічного університету. - Серія "Регіональна економіка". - Випуск 15 (59). - Редкол.: відп. ред. д.е.н., професор Л.Л. Ковальська - Луцьк : ІВВ Луцького НТУ, 2018. -292 с.

УДК 332.144

Шубалий О.М., д.е.н., професор

Луцький національний технічний університет

\title{
ОЦІНКА РЕЗУЛЬТАТИВНОСТІ РОЗВИТКУ СФЕРИ ПРОМИСЛОВОСТІ У РЕГІОНІ
}

У статті проведено оцінку результативності розвитку сфери промисловості на прикладі Волинської області, яка не відноситься до промислово розвинених регіонів України.

Ключові слова: промисловість, регіон, реалізована продукція, промислова продукція, промислові підприємства.

Shubalyi O.

\section{EVALUATION OF THE EFFECTIVENESS OF THE DEVELOPMENT OF INDUSTRY IN THE REGION}

The article assesses the impact of the development of industry in the Volyn region, which does not belong to the industrialized regions of Ukraine.

Industry in the Volyn region is considered to be important and priority parts of the regional economic complex, because it provides jobs for a significant part of the population of the region. But the largest industrial production enterprises are located mainly in the cities of the region - it is Lutsk, Novovolynsk, Kovel, Kivertsi, and also in Lutsk region. Based on the analysis of trends in the main indicators of industrial development in the Volyn region, it was found that volumes of sold products in the period of 2012-2016 increased by 2 times, but the real growth indices were less optimistic, and in the years 2014-2015 they were decreasing. Negative trends include the reduction of the number of workers in the industry. Among the positive points can be highlighted increase in the profitability of industry in 2016 after the lossy previous year. At the same time, the profitability of products remains low, and the volume of capital investment does not have a tendency to increase.

In the course of the research it was revealed that the contribution of the sphere of industry to the economic development of the Volyn region was not stable. After all, in 2013-2014, the share of industry in the gross value added decreased to $14.4 \%$. On the other hand, the share of workers in this sector was the lowest in 2014 - $21.6 \%$, and the share of capital investments dropped sharply in 2016 to $26.3 \%$ after a sharp increase in 2015 to $44.9 \%$. Thus, industry does not show a stable contribution to the economy of the region. The total volume of sales in industry has a tendency to increase. But this growth was achieved mainly due to a sharp increase of more than 3 times the volume of sales of medium-sized industrial enterprises, as well as a slight increase of more than 2 times the volume of sales of small 
Економічні науки: збірник наукових праиь Луиького національного технічного університету. - Серія "Регіональна економіка". - Випуск 15 (59). - Редкол.: відп. ред. д.е.н., професор Л.Л. Ковальська - Луцьк : ІВВ Луиького НТУ, 2018. -292 с.

enterprises. The most developed types of industrial activities in the Volyn region include the production of food and beverages, the manufacture of wood and wood products, as well as machine building. Among the main types of industrial production, the championship in the structure of the volume of industrial products sold confidently holds the processing industry. But its share after 2015 is reduced to $79.9-80.3 \%$ compared to $87.2 \%$ in 2015 . In other words, in general it is possible to note the raw orientation of industrial types of economic activity in the Volyn region.

Thus, the industry is characterized by unstable tendencies in a number of key economic indicators of activity, which requires further analysis of trends in the rate of change in the use of personnel in the industry in the region. enterprises.

Key words: industry, region, realized products, industrial products, industrial

\section{Шубалый А.M. \\ ОЦЕНКА РЕЗУЛЬТАТИВНОСТИ РАЗВИТИЯ СФЕРЫ ПРОМЫШЛЕННОСТИ В РЕГИОНЕ}

В статье проведена оценка результативности развития сферы промышленности на примере Волынской области, которая не относятся к промышленно развитым регионам Украины.

Ключевые слова: промышленность, регион, реализованная продукция, промышленная продукция, промышленные предприятия.

\section{Постановка проблеми у загальному вигляді і її зв'язок} 3 важливими науковими та практичними завданнями. Промисловість відноситься до пріоритетних сфер національної економіки, адже покликана генерувати створення нових доданих вартостей, впроваджувати сучасні технології виробництва, забезпечувати економічну безпеку країни загалом. Тому підвищується актуальність досліджень, які стосуються оцінки результативності розвитку промисловості в окремих регіонах, особливо тих, які не відносяться до промислово розвинених.

\section{Аналіз останніх досліджень, у яких започатковано вирішення проблеми. Різноманітні проблеми розвитку промисловості на національному та регіональному рівнях були об'єктами наукових досліджень багатьох відомих вчених, а також провідних навчальних закладів і наукових установ, серед яких можна виділити Інститут економіки та прогнозування, Інститут регіональних досліджень, Інститут економіки промисловості НАН України та багато інших [2-6; 8].}


Економічні науки: збірник наукових праџь Луцького національного технічного університету. - Серія "Регіональна економіка". - Випуск 15 (59). - Редкол.: відп. ред. д.е.н., професор Л.Л. Ковальська - Луцьк : ІВВ Луцького НТУ, 2018. -292 с.

Цілі статті. Основна ціль дослідження - провести аналіз та оцінку результативності розвитку сфери промисловості на прикладі окремого регіону - Волинської області.

Виклад основного матеріалу дослідження 3 повним обгрунтуванням отриманих наукових результатів. На початковому етапі проведено аналіз основних показників розвитку промисловості у регіоні за 2012-2016 рр. (табл. 1).

Таблиця 1

Основні показники розвитку промисловості у Волинській області за період 2012-2016 pp.

\begin{tabular}{|c|c|c|c|c|c|c|c|c|c|c|c|}
\hline \multirow[b]{2}{*}{ Показники } & \multicolumn{5}{|c|}{ Роки } & \multirow{2}{*}{\multicolumn{3}{|c|}{\begin{tabular}{|c|} 
Абсол. відх. \\
$2016 / 2015 / \mid 2016$ \\
\end{tabular}}} & \multicolumn{3}{|c|}{ Відносн. відх., \% } \\
\hline & 2012 & 2013 & 2014 & 2015 & 2016 & & & 2016 & \begin{tabular}{|l|}
$2016 /$ \\
2015
\end{tabular} & $\begin{array}{l}2015 \\
2014\end{array}$ & $\begin{array}{l}2016 / \\
2012 \\
\end{array}$ \\
\hline $\begin{array}{lr}\text { Обсяг } & \text { реалізо- } \\
\text { ваної } & \text { промислов. } \\
\text { продук., млн.грн }\end{array}$ & 11298 & 310906 & 613683 & 19426 & 23378 & 3953 & 5743 & 12080 & 20,3 & 42,0 & 106,9 \\
\hline $\begin{array}{lr}\text { Частка } \\
\text { малих підпр. у заг. } \\
\text { обсязі } \\
\text { промисловості, \% }\end{array}$ & 7,8 & 9,1 & 9,2 & 8,9 & 8,2 & $\mid-0,7$ & $\mid-0,3$ & 0,4 & $\mid-7,9$ & $-3,3$ & 5,1 \\
\hline $\begin{array}{l}\text { Індекс пром. прод. } \\
\text { до попер. року, \% }\end{array}$ & 94,5 & 102,9 & 103,2 & 98,6 & 100,2 & 1,6 & $-4,6$ & 5,7 & 1,6 & $-4,5$ & 6,0 \\
\hline $\begin{array}{l}\text { Кількість зайнятих } \\
\text { працівників, осіб }\end{array}$ & 45402 & 243122 & 242821 & 142292 & 42347 & 55 & -529 & -3055 & 0,1 & $-1,2$ & $-6,7$ \\
\hline $\begin{array}{l}\text { Середньооблікова } \\
\text { кількість штатних } \\
\text { працівників, осіб } \\
\end{array}$ & 41823 & 340297 & 739194 & 438460 & $\mid 38085$ & -375 & $\mid-734$ & -3738 & $-1,0$ & $-1,9$ & $-8,9$ \\
\hline $\begin{array}{l}\text { Середньомісячна } \\
\text { зарплата } 1 \text { штатн. } \\
\text { працівника, грн } \\
\end{array}$ & 2707 & 2976 & 3426 & 4334 & 5532 & 1198 & 908 & 2825 & 27,6 & 26,5 & 104,4 \\
\hline $\begin{array}{l}\text { Фін. результат до } \\
\text { оподатк., млн грн }\end{array}$ & 234,9 & 226,8 & -217 & 298,7 & 607,7 & 309 & 516,2 & 372,8 & 103,4 & -237 & 158,7 \\
\hline \begin{tabular}{|lr} 
Частка & підприєм- \\
ств, які & одержали \\
збиток & до \\
оподаткування, \%
\end{tabular} & 38,8 & 36,9 & 33,6 & 27,8 & 26,2 & $-1,6$ & $-5,8$ & $-12,6$ & $\mid-5,8$ & $-17,3$ & $-32,5$ \\
\hline $\begin{array}{|lc|}\text { Чистий } & \text { прибуток } \\
\text { (збиток) } & \text { пром. } \\
\text { підпр., млн грн }\end{array}$ & 73,1 & 101,7 & -360 & $-16,4$ & 355,9 & 372,3 & 343,8 & 282,8 & $|-2270|$ & $-95,4$ & 386,9 \\
\hline
\end{tabular}


Економічні науки: збірник наукових праиь Луиького національного технічного університету. - Серія "Регіональна економіка". - Випуск 15 (59). - Редкол.: відп. ред. д.е.н., професор Л.Л. Ковальська - Луцьк : ІВВ Луцького НТУ, 2018. -292 с.

\begin{tabular}{|l|r|r|r|r|r|r|r|r|r|r|r|}
\hline $\begin{array}{l}\text { Рентабельність } \\
\text { операційної } \\
\text { діяльності, \% }\end{array}$ & 3,9 & 3,9 & 6,8 & 6,4 & 4,5 & $-1,9$ & $-0,4$ & 0,6 & $-29,7$ & $-5,9$ & 15,4 \\
\hline $\begin{array}{l}\text { Валова додана } \\
\text { вартість, млн.грн }\end{array}$ & 2885 & 2700 & 3136 & 4743 & & & 1607 & & 0,0 & 51,2 & \\
\hline $\begin{array}{l}\text { Капітальні інвес-- } \\
\text { тиції, млн грн }\end{array}$ & 657,1 & 782,9 & 933,9 & 2771 & 1679 & -1092 & 1837 & 1022 & $-39,4$ & 196,7 & 155,5 \\
\hline
\end{tabular}

Примітка. Побудовано автором на основі $[1,7,9]$.

Показник обсягу реалізованої промислової продукції за аналізований період збільшився з 11298 млн грн у 2012 році до 23378 млн грн у 2016 році, або у 2,1 рази, а найбільший приріст відбувся у 2015 році - на 42,0\% до попереднього року. Поступово розвивається сегмент малих промислових підприємств, частка продукції яких у загальному обсязі продукції промисловості збільшилася з 7,8\% у 2012 році до 8,2\% у 2016 році. Разом 3 тим, нестабільними були індекси промислової продукції, які у період економічної кризи 2012 року зменшилися до 94,5\%, але у період активної фази АТО 2015 року становили 98,6\%. Разом 3 тим, динамічного відновлення промисловості не спостерігається, адже у 2016 році цей показник становив лише 100,2\%. До негативних тенденцій розвитку даного виду економічної діяльності можна віднести невпинне зменшення кількості зайнятих працівників 3 45,4 тис осіб до 42,3 тис осіб, або на 6,7\% за увесь період. Тоді як зменшення середньооблікової чисельності штатних працівників було ще більш значним - на 8,9\% за увесь період. Середньомісячна номінальна заробітна плата у галузі має тенденцію до зростання з 2707 грн у 2012 році до 5532 грн у 2016 році, або у 2 рази.

Тоді як реальна купівельна спроможність населення знизилася у понад як 3 рази, що можна прослідкувати за зміною курсів основних зарубіжних валют до гривні за цей період.

Разом 3 тим, підприємства промисловості регіону майже протягом усього періоду забезпечували позитивний фінансовий результат до оподаткування за підсумками своєї економічної діяльності. Тільки у складному, з позицій необхідності боротьби за незалежність, 2014 році було отримано збиток у розмірі 
Економічні науки: збірник наукових праиь Луиького національного технічного університету. - Серія "Регіональна економіка". - Випуск 15 (59). - Редкол.: відп. ред. д.е.н., професор Л.Л. Ковальська - Луцьк : ІВВ Луиького НТУ, 2018. -292 с.

217,5 млн грн. Можна відмітити різке зростання у 2 рази фінансового результату до оподаткування галузі у 2016 році, що свідчить про поступове відновлення ефективної роботи. Також серед позитивних моментів у цьому контексті $\epsilon$ те, що частка підприємств, які одержали збиток протягом аналізованого періоду зменшилася з 38,8\% у 2012 році до 26,2\% у 2016 році.

Вивчення динаміки показника чистого прибутку свідчить, що після збиткових 2014-2015 pp. отримано найбільший прибуток у 2016 році, який досягнув 355,9 млн грн. Але серед негативних моментів можна відзначити зменшення рентабельності операційної діяльності у 2016 році до 4,5\%, тоді як у 2014-2015 рр. він становив 6,4-6,8\%.

До позитивних результатів можна також віднести зростання суми валової доданої вартості, особливо у 2015 р. у 1,5 рази, а до негативних - зменшення у 2016 р. на 39,4\% суми капітальних інвестицій після їх різкого зростання у 2015 р.

Після цього проведено аналіз зміни частки промисловості в основних показниках розвитку економіки Волині за період 2012-2016 рр. (рис. 1).

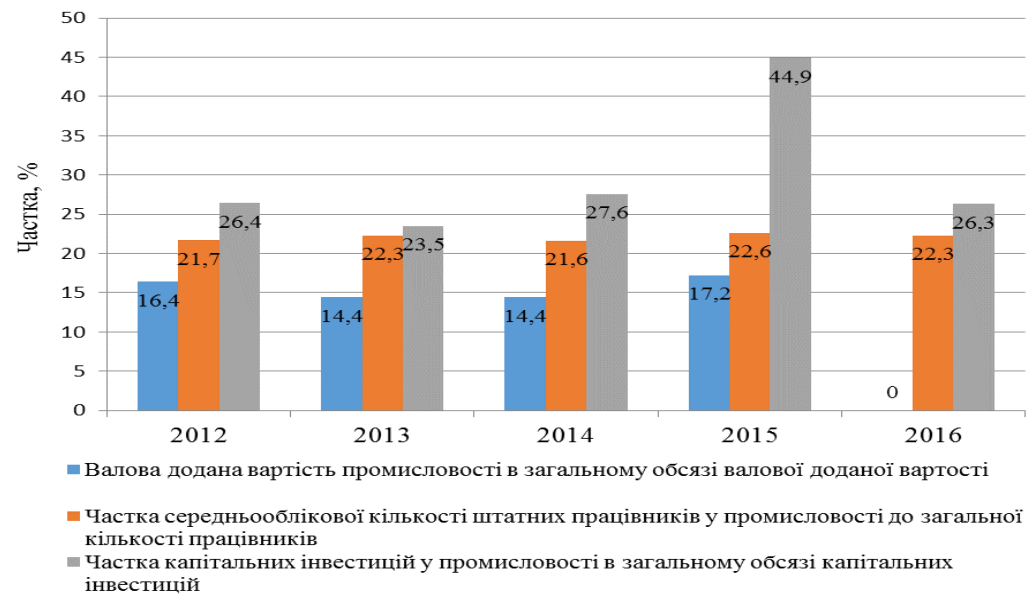

Рис. 1. Зміна частки промисловості в основних показниках розвитку економіки Волині за період 2012-2016 pp., \% (побудовано автором за даними $[1,7,9]$ ) 
Економічні науки: збірник наукових праџь Луцького національного технічного університету. - Серія "Регіональна економіка". - Випуск 15 (59). - Редкол.: відп. ред. д.е.н., професор Л.Л. Ковальська - Луцьк : ІВВ Луцького НТУ, 2018. -292 с.

Загалом видно, що внесок сфери промисловості в економічний розвиток Волинської області не мав стабільної динаміки. Адже у 2013-2014 pр. частка промисловості у показнику валової доданої вартості зменшилася до 14,4\%. 3 іншого боку, частка працівників даної галузі була найнижчою у 2014 році - 21,6\%, а частка капітальних інвестицій різко зменшилася у 2016 році до $26,3 \%$ після різкого зростання у 2015 році до 44,9\%. Таким чином, промисловість не демонструє стабільного внеску в економіку регіону.

Важливе значення має також дослідження динаміки обсягу реалізованої продукції за розміром промислових підприємств Волинської області за 2012-2016 рр. (рис. 2).

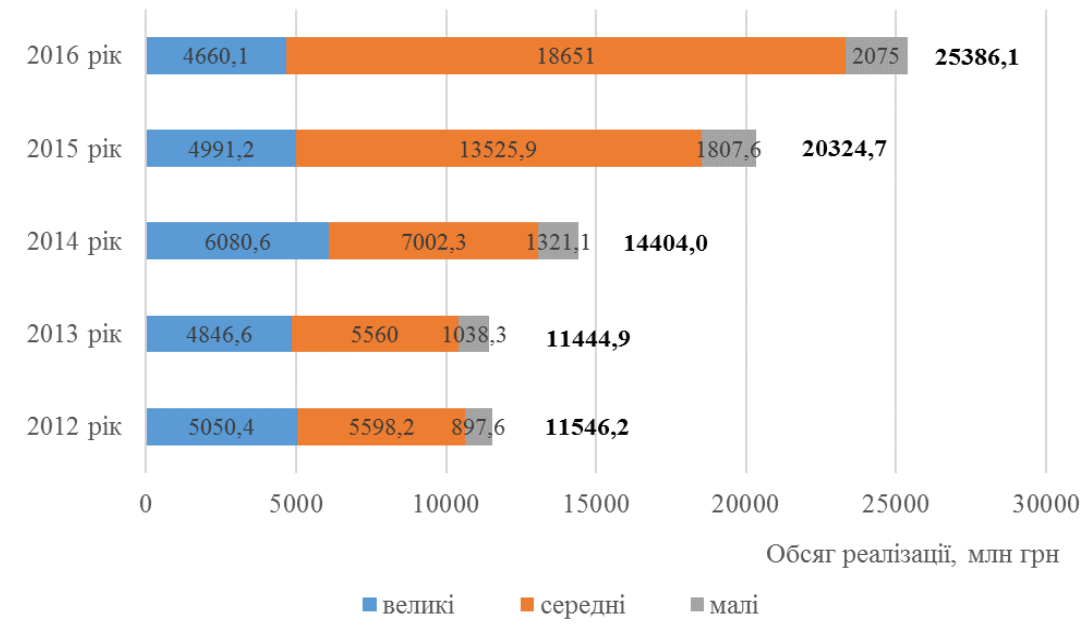

Рис. 2. Динаміка обсягу реалізованої продукції за розміром промислових підприємств Волинської області за 2012-2016 pp. (побудовано автором за даними $[1,7,9]$ )

Як бачимо, протягом аналізованого періоду загальний обсяг реалізованої продукції у промисловості мав тенденцію до зростання. Але це зростання було досягнуто переважно за рахунок різкого збільшення у понад 3 рази обсягу реалізації середніх промислових підприємств, а також незначного 
Економічні науки: збірник наукових праџь Луцького національного технічного університету. - Серія "Регіональна економіка". - Випуск 15 (59). - Редкол.: відп. ред. д.е.н., професор Л.Л. Ковальська - Луцьк : ІВВ Луцького НТУ, 2018. -292 с.

зростання у понад 2 рази обсягу реалізації малих підприємств. Як значний негатив можна відмітити зменшення обсягу реалізації великих підприємств. Така тенденція $є$ доволі негативною, адже розвиток великих промислових підприємств $€$ запорукою економічної стабільності регіону та забезпечення зайнятості населення регіону.

На наступному етапі вивчено динаміку обсягів реалізації продукції у розрізі основних видів переробної промисловості Волинської області за 2012-2016 рр. (рис. 3).

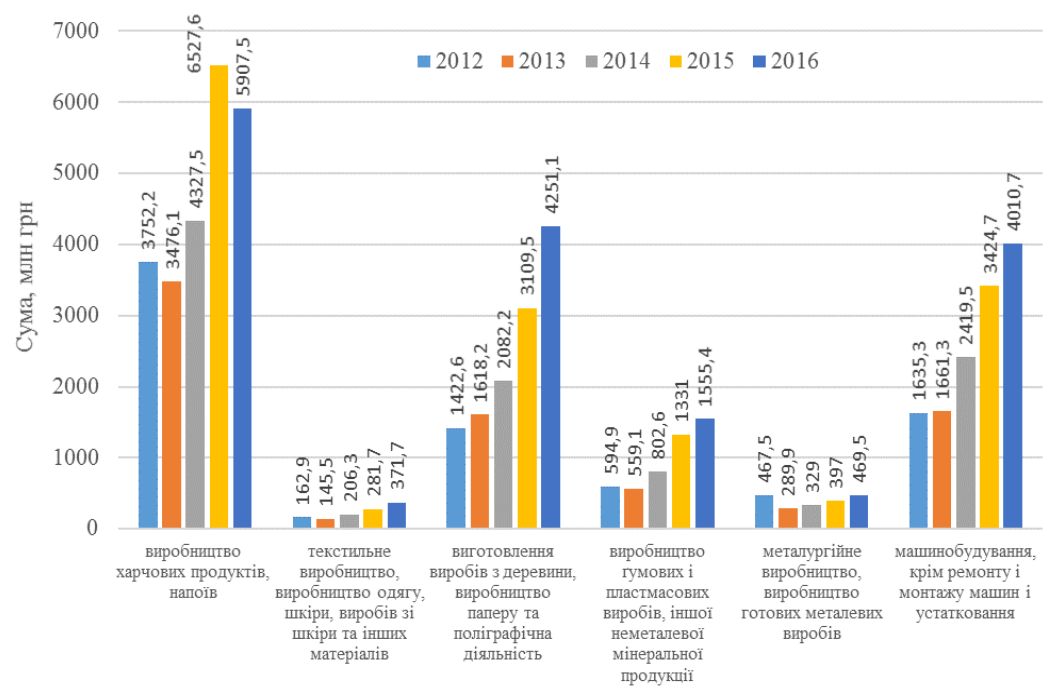

Рис. 3. Динаміка обсягів реалізації продукції у розрізі основних видів переробної промисловості Волинської області за 2012-2016 рр. (побудовано автором за даними $[1,7,9]$ )

До найбільш розвинутих видів промислової діяльності у Волинській області можна віднести виробництво харчових продуктів і напоїв, виготовлення деревини та виробів 3 деревини, а також машинобудування. Поступово розвивається виробництво гумових і пластмасових виробів, виробництво готових металевих виробів, а також текстильне виробництво. 
Економічні науки: збірник наукових праиь Луиького національного технічного університету. - Серія "Регіональна економіка". - Випуск 15 (59). - Редкол.: відп. ред. д.е.н., професор Л.Л. Ковальська - Луцьк : ІВВ Луиького НТУ, 2018. -292 с.

Нестабільним $\epsilon$ виробництва харчових продуктів i напоїв, обсяги яких у 2013 році та в 2016 році мали тенденцію до зниження. Це також було характерно для виробництва металевих виробів. Поряд 3 цим доцільно також проаналізувати зміну структури обсягу реалізованої промислової продукції за видами діяльності у Волинській області за 2012-2017рр. (рис. 4).

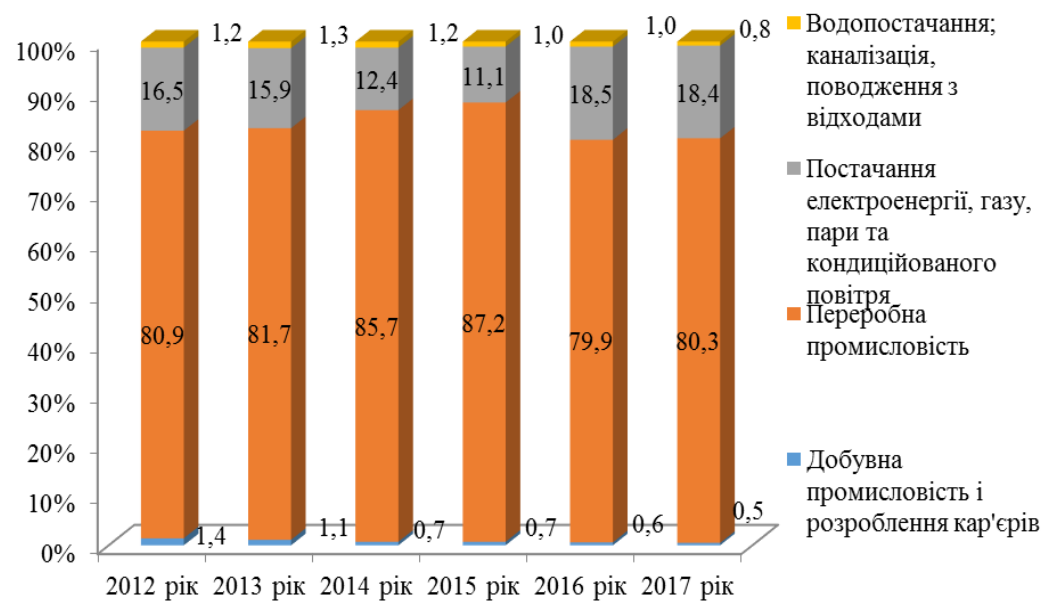

Рис. 4. Зміна структури обсягу реалізованої промислової продукції за видами діяльності у Волинській області за 2012-2017 pр. (побудовано автором за даними $[1,7,9]$ )

Серед основних видів промислового виробництва першість у структурі обсягу реалізованої промислової продукції впевнено утримує переробна промисловість. Але ії частка після 2015 року знижується до 79,9-80,3\% порівняно 3 87,2\% у 2015 році. Тобто в цілому можна відмітити сировинну орієнтацію промислових видів економічної діяльності у Волинській області. Натомість відбулося штучне зростання обсягу реалізованої промислової продукції у сфері постачання електроенергії, газу, пари та кондиційованого повітря з 16,\% у 2012 році до 18,4\% у 2017 році за рахунок різкого підвищення 
Економічні науки: збірник наукових праџь Луцького національного технічного університету. - Серія "Регіональна економіка". - Випуск 15 (59). - Редкол.: відп. ред. д.е.н., професор Л.Л. Ковальська - Луцьк : ІВВ Луцького НТУ, 2018. -292 с.

цін на енергоносії у період обезцінення національної валюти. Незначною, але має тенденцію до зменшення $є$ частка водопостачання; каналізації, поводження з відходами - 3 1,2\% до $0,8 \%$, а також частка добувної промисловості - $31,4 \%$ до $0,5 \%$.

Надалі проведено порівняння індексів зміни обсягу промислової продукції у Волинській області та Україні за 2012-2017 рр. (рис. 5).

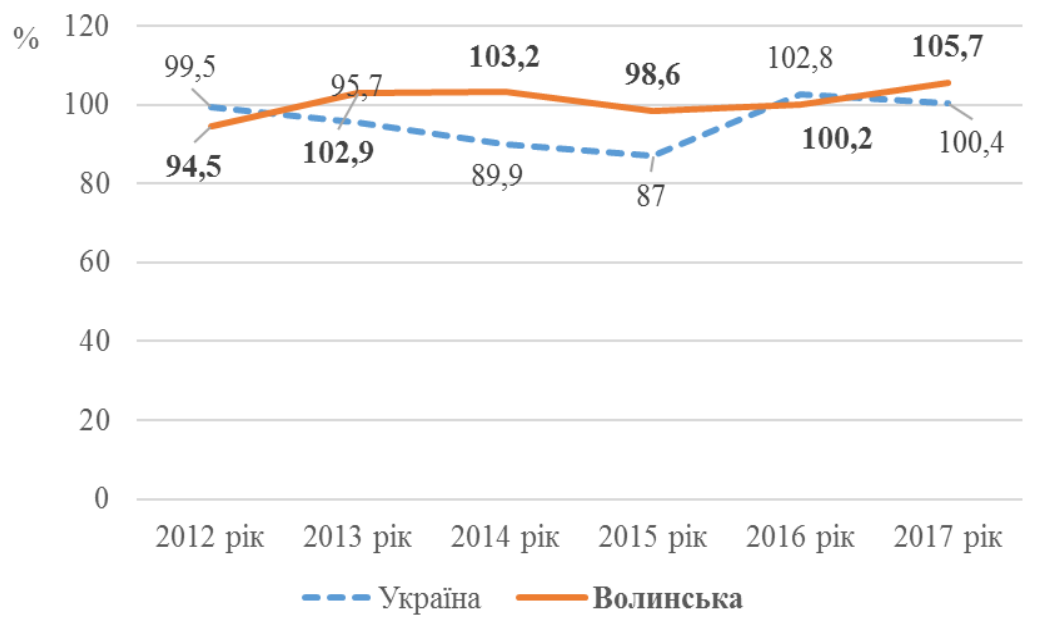

Рис. 5. Порівняння індексів зміни обсягу промислової продукції у Волинській області та Україні за 2012-2017 pp. (побудовано автором за даними $[1,7,9]$ )

На наступному етапі вивчено зміну індексів промислової продукції за видами діяльності у Волинській області за 20132017 рр. (табл. 2). На основі вивчення цих показників можна констатувати, що середньорічний темп приросту обсягу промислової продукції у промисловості за аналізований період становив 102,1\%. Цього було досягнуто за рахунок переважання позитивного впливу більшого зростання індексу текстильного виробництва, виробництва одягу, шкіри, виробів зі шкіри та 
Економічні науки: збірник наукових праџь Луцького національного технічного університету. - Серія "Регіональна економіка". - Випуск 15 (59). - Редкол.: відп. ред. д.е.н., професор Л.Л. Ковальська - Луцьк : ІВВ Луиького НТУ, 2018. -292 с.

інших матеріалів до 105,3\%, а також виробництва коксу та продуктів нафтоперероблення до 104,8\%, продукції машинобудування, крім ремонту i монтажу машин i устаткування - до 104,7\%.

Таблиця 2

Зміна індексів промислової продукції за видами діяльності у Волинській області за 2013-2017 рр. (до попер. року; \%)

\begin{tabular}{|c|c|c|c|c|c|c|}
\hline Вид діяльності & $\begin{array}{l}2013 \\
\text { рік }\end{array}$ & $\begin{array}{c}2014 \\
\text { рік }\end{array}$ & $\begin{array}{c}2015 \\
\text { рік }\end{array}$ & $\begin{array}{l}2016 \\
\text { рiк }\end{array}$ & $\begin{array}{l}2017 \\
\text { рік }\end{array}$ & $\begin{array}{l}\text { Середньо- } \\
\text { річ. темп } \\
\text { росту, \% }\end{array}$ \\
\hline Промисловість всього & 102,9 & 103,2 & 98,6 & 100,2 & 105,7 & 102,1 \\
\hline $\begin{array}{l}\text { Добувна та переробна } \\
\text { промисловість }\end{array}$ & 103,1 & 103,8 & 98,9 & 99,7 & 106,2 & 102,3 \\
\hline $\begin{array}{l}\text { Добувна промисловість } \\
\text { розроблення кар'єрів }\end{array}$ & 105,6 & 73,5 & 114,7 & 70,5 & 82,1 & 87,6 \\
\hline Переробна промисловість, з неї & 103 & 104,6 & 98,6 & 100,4 & 106,6 & 102,6 \\
\hline $\begin{array}{ll}\text { виробництво } & \text { харчових } \\
\text { продуктів, напоїв } & \\
\end{array}$ & 101,7 & 110,3 & 96,1 & 89,2 & 99,8 & 99,2 \\
\hline $\begin{array}{l}\text { текстильне виробництво, } \\
\text { виробництво одягу, шкіри, } \\
\text { виробів зі шкіри та ін. матеріал. }\end{array}$ & 103,3 & 90,8 & 115,1 & 94,5 & 127,1 & 105,3 \\
\hline $\begin{array}{l}\text { виготовлення виробів } \\
\text { деревини, виробництво паперу } \\
\text { та поліграфічна діяльність } \\
\end{array}$ & 108,7 & 94 & 99,4 & 111,9 & 110 & 104,6 \\
\hline $\begin{array}{l}\text { виробництво каксу } \\
\text { продуктів нафтоперероблення }\end{array}$ & 122,6 & 92 & 108,9 & 88,9 & 115,8 & 104,8 \\
\hline $\begin{array}{l}\text { виробництво хімічних речовин } \\
\text { і хімічної продукції }\end{array}$ & 104,6 & 110,4 & 97,4 & 96,4 & 91,5 & 99,8 \\
\hline $\begin{array}{lc}\text { виробництво гумових } \\
\text { пластмасових } \\
\text { неметалевої мінерал. продукції }\end{array}$ & 97,5 & 105,6 & 102,3 & 99 & 104,7 & 101,8 \\
\hline $\begin{array}{lr}\text { металургійне } & \text { виробництво, } \\
\text { виробництво } & \text { готових } \\
\text { металевих виробів, крім машин } \\
\text { і устаткування } \\
\end{array}$ & 81,6 & 78 & 85 & 120,2 & 117,5 & 94,8 \\
\hline $\begin{array}{l}\text { машинобудування, крім } \\
\text { ремонту і монтажу машин i } \\
\text { устаткування }\end{array}$ & 103,2 & 112,7 & 108,4 & 92,6 & 108 & 104,7 \\
\hline $\begin{array}{l}\text { Постачання електроенергії, } \\
\text { газу, пари та кондицій. повітря }\end{array}$ & 101,1 & 98 & 95,6 & 105,4 & 101,4 & 100,2 \\
\hline
\end{tabular}

Примітка. Побудовано автором на основі $[1,7,9]$. 
Економічні науки: збірник наукових праџь Луцького національного технічного університету. - Серія "Регіональна економіка". - Випуск 15 (59). - Редкол.: відп. ред. д.е.н., професор Л.Л. Ковальська - Луцьк : ІВВ Луцьького НТУ, 2018. -292 с.

Промисловість у Волинській області відносять до важливих та пріоритетних ланок регіонального господарського комплексу, адже вона забезпечує робочі місця для значної частини населення регіону. Але найбільші промислові виробничі підприємства розміщені переважно в містах області це м. Луцьк, м. Нововолинськ, м. Ковель, м. Ківерці, а також у Луцькому районі.

Висновки. На основі аналізу тенденцій зміни основних показників розвитку промисловості у Волинській області виявлено, що обсяги реалізованої продукції за період 2012-2016 рр. зросли у 2 рази, але індекси реального приросту не такі оптимістичні, а у 2014-2015 рр. відбувалося їх зниження. До негативних тенденцій можна віднести зменшення чисельності працівників галузі. Серед позитивних моментів можна виділити підвищення прибутковості роботи промисловості у 2016 році після збиткового попереднього року. Разом $з$ тим, рентабельність продукції залишається низькою, а обсяги капітальних інвестицій не мають тенденції до зростання.

Отже, сфера промисловості характеризується нестабільними тенденціями зміни ряду основних економічних показників діяльності, що вимагає проведення подальшого аналізу тенденцій зміни показників ефективності використання персоналу у промисловості регіону.

6. Волинь-2016: статистичний щорічник / За ред. В.Ю. Науменка. - Луцьк: Головне управління статистики у Волинській області, 2017. - 457 с.

7. Високотехнологічна сфера промисловості України: ресурсні можливості розвитку: [монографія] / [Одотюк І.В., Саліхова О.Б., Мусіна Л.А. та ін.]; за ред. д.е.н. Одотюка І.В.; НАН України, ДУ “Ін-т екон. та прогнозув. НАН України". - К., 2013. - 392 с.

8. Засади модернізації виробничої інфраструктури України: [кол. монографія] / [Піріашвілі Б.З., Чиркін Б.П., Никифорук О.І. та ін.]; ДУ "Ін-т екон. та прогнозув. НАН України". - К., 2014. - 276 с.

9. Іщук С.О. Промисловість Львівської області: ключові тенденції та перспективи розвитку / С.О. Іщук // Соціально-економічні проблеми сучасного періоду України / НАН України. Ін-т регіональних досліджень. Львів, 2014. - Вип. 3 (107). Регіональна політика в Україні: сучасний стан та шляхи активізації. - С. 275-284. 
Економічні науки: збірник наукових праиь Луиького національного технічного університету. - Серія "Регіональна економіка". - Випуск 15 (59). - Редкол.: відп. ред. д.е.н., професор Л.Л. Ковальська - Луцьк : ІВВ Луиького НТУ, 2018. -292 с.

10. Кіндзерський Ю.В. Промисловість України: стратегія і політика структурно-технологічної модернізації: [монографія] / Ю.В. Кіндзерський; НАН України, ДУ “Ін-т екон. та прогнозув. НАН України”. - К., 2013. $536 \mathrm{c}$.

11. Кудря Я.В. Оцінка тенденцій розвитку промисловості Західного регіону України / Я.В. Кудря, О.С. Процевят // Соціально-економічні проблеми сучасного періоду України. - 2015. - Вип. 4. - С. 45-52. - Режим доступу: http://nbuv.gov.ua/UJRN/sepspu_2015_4_12

12. Офіційний веб-сайт Головного управління статистики у Волинській області [Електронний ресурс]. - Режим доступу: http://www.lutsk.ukrstat.gov.ua

13. Промисловість і промислова політика України 2013: актуальні тренди, виклики, можливості: [наук.-аналіт. доповідь] / O.I. Амоша, В.П. Вишневський, Л.О. Збаразська та ін.; за заг. ред. В.П. Вишневського; НАН України, Ін-т економіки пром-сті. - Донецьк, 2014. - 200 с.

14. Промисловість Волині 2016: статистичний збірник / За ред. Л.С. Баранюк. - Луцьк: Головне управління стат. у Волинській області, 2017. - 138 с. 